\title{
INFORMATION TECHNOLOGY IN IMPROVING AGRICULTURAL MARKETING
}

\author{
Mutisari Rini*, Nugroho Condro Puspo, Aprilia Anisa \\ Department of Agricultural Socio-Economics, Faculty of Agriculture, \\ University of Brawijaya, Indonesia \\ *E-mail: rinimutisari@ub.ac.id
}

\begin{abstract}
Rapidly developing technology fosters economic growth; unfortunately there are still many who have not used technological advances, especially in the marketing of agricultural products. This research aims to analyze the factors that affect the interest in the use of information technology in marketing agricultural products. Logistic regression is used to answer the research objectives. Farmers who have a high level of information technology knowledge have a higher chance of accessing information technology in marketing thus that information communication technology training are needed to improve farmers' welfare.
\end{abstract}

\section{KEY WORDS}

Information technology, marketing, agricultural products, internet.

Agricultural production factors are at the core of agriculture, and have an important influence on the value of agricultural output ( $\mathrm{Li}$ and $\mathrm{Li}, 2018$ ). The factors of agricultural production that we know so far are land, capital, labor and technology. Ensuring the area of cultivated land and allocating factors of agricultural production are important guarantees for increasing agricultural output (Zhang et al, 2016). One of the means of production that is often forgotten is information. Information really determines the success of a farmer's business, for example whether one's business will succeed or not, profitable or not and so on. Information on how much the market needs and availability of certain commodities will determine how many commodities must be produced by farmers thus the business can be profitable. Advances in technology today bring us to the global world, including in the field of information. Today's information globalization is no longer only interpreted as a mass communication flow in the sense of merely broadcasting television broadcasts and entertainment, but it includes expanding the flow of scientific and technological information through the digital internet which is driving the expansion of the horizon of information and human insight.

The agricultural sector as a sector that is relied on to meet food availability must be able to adapt and be able to take advantage of the internet-based digital technology. This is because, the future of agriculture will no longer only take place conventionally but will be replaced by the role of internet-based technology. Thus total support from the agricultural sector becomes important for agricultural producers (Faical and Ali, 2016).

In recent decades, knowledge as input into the economic system has surpassed natural resources in determining and shaping a country's path towards development and economic growth. The generation and diffusion of knowledge is the core of a knowledgedriven economy, becoming a very important component in the search for a nation for economic competitiveness and sustainable growth (Gouvea, Kapelianis and Kassicieh, 2018). Industry 4.0 has been considered a new industrial stage where several emerging technologies converge to provide digital solutions (Frank, Dalenogare and Ayala, 2019).

Through the implementation of the 4.0 Industrial Revolution in the agricultural sector today the world needs a form of industrial development that cannot be avoided. The 4.0 Industrial Revolution that is developing at this time is no longer talking about automation of tools, but rather the use of machines that are integrated directly with the internet network that can quickly provide information to the entire community.

Technology development influences the country's economic level and determines the country's competitive position (Jiang et al, 2018). The development of information technology 
should be utilized in the marketing sector of agricultural products, considering that agricultural products that are not durable and are easily damaged require a separate marketing method, to be directly into the hands of consumers. For this reason, it is necessary to empower farmers with a cooperative farming model to reduce the marketing chain. Meanwhile, to improve agriculture, farmers are entitled to benefit from technological advancements.

Based on the explanation above, this study will examine the use of information technology (internet) in increasing marketing of agricultural products, by analyzing the factors that affect the interest in the use of information technology in marketing agricultural products.

\section{LITERATURE REVIEW}

Awareness of the importance of Information and Communication Technology which is usually called ICT (Information and Communication Technology), it is not only a monopoly among large entrepreneurs but also growing among small entrepreneurs and other community forces, such as Cooperatives, Farmers Groups, and ordinary people. ICT is believed to play an important role in business development, organizational institutions, and is also able to encourage the acceleration of economic activities and people's lives.

E-commerce refers to the use of the internet to market, buy and sell goods and services, exchange information, and create and maintain web-based relationships between participating entities (Fruhling and Digman, 2000). Based on the impact shown in the industrial retail market (Elia, Lefebvre, \& Lefebvre 2007), e-commerce is believed to have the potential to increase profitability in the agricultural market by increasing sales and reducing search and transaction costs. The creation of an electronic market that is expected to be more transparent and competitive than the physical market can attract more consumers by increasing demand and increasing the company's strategic position with customers who are looking for a specific product niche or have geographical restrictions (Montealegre, Thompson \& Eales, 2007 )

The influence of e-commerce mainly is as a medium of promotion, communication and information. Utilization is very influential on the effectiveness and efficiency of work processes, if intensely and maximally carried out. The benefits felt by business people directly and indirectly have a positive influence on the farming community involved, especially from the increasingly broad marketing channels of business people that increase production demand and encourage production procurement among the farming community, which is always expected to increase production with standards determined quality, with more integrated farming activities to produce more and more quality, then the opportunity to improve the lives of farmers and their families is wide open (Swandayani, 2014). Melly (2000) analyzes the use of the internet network is very effective and efficient in terms of time and cost for marketing activities are also very useful to promote the commodity / service of a company, and to exchange internet information is also a relatively inexpensive promotion compared to other promotional media. The reach of the internet is unlimited worldwide with a growing number of users every time.

Agricultural products have perishable characteristics and take up space (bulkiness), this affects quality and price so that it demands the distribution chain of these products to be closer to consumers. The concept of e-marketing does not have to be face-to-face in making product purchase transactions, so as to shorten the time to get the product consumers want. E-marketing in its activities perform marketing management functions in a more modern way. According to Mohammed et al (2003), e-marketing is a process for building and maintaining relationships with customers through online activities as a means for the exchange of opinions, products, and services so as to achieve the shared goals of both groups. Information flow, structure and behavior of traders in the market will also affect the formation of commodity prices. Information about the type, quality and time of a commodity needed by consumers will be very useful for farmers in production planning. The market structure also affects the price setting, so far farmers in marketing their commodities are dealing with the oligopoly market structure while the final consumers are dealing with the oligopoly market, 
this will have an impact on losses on the part of farmers and consumers while traders enjoy more profits (Paranata 2015). Efforts to use e-commerce are expected to further shorten the marketing chain of agribusiness products, so as to increase people's purchasing power and increase farmers' incomes.

According to Sulthoni (2016), the use of e-commerce allows companies to sell products directly to other companies or to end consumers. The potential to bypass distribution channels brings support for expanding the market by setting lower prices when it comes to final consumers, this is because it does not involve many levels or processes in distribution that want to get more profit by increasing selling prices to consumers, but directly from farmers to end consumers.

\section{METHODS OF RESEARCH}

In this research, primary data collection using survey methods through direct interviews with farmers. As a unit of analysis are farmers who carry out horticultural farming as well as utilizing and not utilizing internet-based information technology, especially in marketing at least 1 planting season. Determination of sample size is based on consideration of uniformity, precision, cost, labor and time available and based on the analysis plan.

There are two types of respondents used as the object studied so that the sampling method used is different. First for farmers respondents who do marketing in a conventional manner, using a multi-stage cluster sampling method. Second, for farmer respondents who use the internet, use the Snowball Sampling method. Where the Snowball sampling method will begin by finding one key respondent (farmer and internet user, or farmer group leader), then from there it will be known to other internet users farmers in selected locations.

While the analysis method used is Logistic Regression. The logit model is a regression model specifically designed to handle regression analysis with the dependent variable in the form of a probability variable, such as a variable whose value ranges from 0 to 1 . The logit model allows the estimation of the regression equation to keep the predicted results of the dependent variable in the range of values between 0 and 1.

This study uses logit model regression analysis which is needed to answer whether the variables of age, level of education, gender, farming experience and knowledge of internetbased information technology will influence farmers' interest in utilizing information technology in marketing or vice versa. The variables used in the model are as follows.

Dependent variable: $Y=1$, if farmers use information technology in marketing; $Y=0$, if farmers do not utilize information technology in marketing.

The independent variable in this model serves to explain the use of information technology in marketing agricultural products. The variable consists of 5 , namely: $\mathrm{X} 1=$ Age; X2 = Education level; X3 = Gender; X4 = Farming Experience; X5 = knowledge of internetbased information technology.

The five variables are measured based on the total score from the measurement of each indicator held.

$$
\begin{gathered}
\operatorname{Prob}(x)=P \\
\operatorname{Prob}(x)=1-P
\end{gathered}
$$

Because the probability $(\mathrm{P})$ must lie between 0 and 1 , there are restrictions:

$$
0 \leq E[y \mid x] \leq 1
$$

Interpretation of the logit model shows the probability that farmers who have an interest in utilizing information technology in marketing agricultural products are shown by the equation:

$$
\begin{gathered}
\operatorname{Prob}(x)=P=\frac{e^{z}}{1+e^{z}} \\
Z=\beta_{0}+\beta_{1} X_{1}+\beta_{2} X_{2}+\beta_{3} X_{2}+\beta_{4} X_{4}+\beta_{5} X_{5}
\end{gathered}
$$


If $P$ is the probability of farmers who have an interest in utilizing information technology in marketing agricultural products, then the probability of farmers who do not have an interest in using information technology in marketing agricultural products is:

$$
\begin{gathered}
\operatorname{Prob}(x)=1-P=\frac{1}{1-e^{z}} \\
\frac{P}{1-P}=\frac{1+e^{z}}{1+e^{-z}}=e^{z}
\end{gathered}
$$

$\frac{P}{1-P}$ (Odds ratio), is the comparison between probability of farmers who have an interest in utilizing information technology in marketing agricultural products toward probability of farmers who do not have an interest in using information technology in marketing agricultural products. Thus, the logit model in this research is:

$$
L i=\ln \left[\frac{P}{1-P}\right]=y=\beta_{0}+\beta_{1} X_{1}+\beta_{2} X_{2}+\beta_{3} X_{2}+\beta_{4} X_{4}+\beta_{5} X_{5}
$$

Where: $\beta 1-\beta 4=$ regression coefficient; $P=$ the probability of farmers who have an interest in utilizing information technology in marketing agricultural products; $P-1=$ the probability of farmers not having an interest in utilizing information technology in marketing agricultural products.

In logistic regression (logit), hypothesis testing cannot be done by the same method as in linear regression. In linear regression where the response variable is normally distributed the $\mathrm{F}$ test and t test are used to test the significance of the explanatory variables. However, the distribution of response variables in logistic regression is the Bernoulli distribution so different statistical tests must be used.

The $G$ test is used to see whether all parameters can be entered into the model by looking at $\mathrm{X} 2$ arithmetic. If $\mathrm{X} 2$ arithmetic is greater than $\mathrm{X} 2$ tables, it can be concluded that all parameters can be entered into the model.

Log likelihood is used to see the overall model or overall model fit. The conditions are as follows: if the Loglikelihood in Block Number $=0$ is greater than the loglikelihood value in Block Number $=1$, then the regression model can be said to be good; if the Loglikelihood in Block Number $=0$ is smaller than the loglikelihood value in Block Number $=1$, it can be said that the regression model is not good.

In the usual regression model the correlation coefficient is known as R2 or R square. In the logit model Cox \& Snell R Square or Nagelkerke R Square can be used on the SPSS program package. Goodness of Fit Test is used to determine the size of the accuracy of the model used, which is expressed by what percentage of the dependent variable, that is, interest can be explained by the independent variables entered into the logit regression model. The Goodness of Fit formula is as follows:

$$
\text { Negelkerke } R^{2}=\frac{-2 \log \log L_{0}\left(2-\log L_{1}\right)}{-2 \log L_{0}}
$$

Where: $L 0=$ likelihood value if all regression coefficients $(\beta)$, except intercepts $(\beta 0)$ are 0 ; $\mathrm{L} 1=$ likelihood values for all regression coefficients $(\beta 0$ and $\beta 1)$ in the model.

Wald test like the $t$ test in linear regression that serves to determine the effect of each estimated coefficient on the model. The hypothesis is as follows:

- $\mathrm{H} 0: \beta \mathrm{i}=0$, meaning that each independent variable does not influence farmers to utilize information technology in marketing agricultural products;

- Ha: $\beta i \neq 0$, meaning, each independent variable influences farmers to utilize information technology in marketing agricultural products. 
This test is done by comparing the Wald statistical value on the independent variables obtained from logistic regression analysis with the Chi-square table at a 95\% confidence level. Wald test formula as follows:

$$
\text { Wald }=\left(\frac{B}{S E}\right)^{2}
$$

Where: $\mathrm{B}=$ Logistic regression coefficient; $\mathrm{SE}=$ Standard error.

Partial correlation is used to see the contribution of each independent variable to the dependent variable. The amount ranges from -1 to +1 . A positive value indicates that the increase in the value of the variable has an impact on increasing Likelihood. A low $R$ value indicates that the influence of the independent variable is dominant in the decision making process of farmers in utilizing information technology in marketing agricultural products. The partial correlation formula $(R)$ is as follows:

$$
R=\sqrt{\left(\frac{\text { wald statistic }-2 k}{-2 L L o}\right)}
$$

Where: $\mathrm{R}=$ Partial correlation coefficient; $\mathrm{K}=$ Number of independent variables; Llo $=$ Likelihood based on the model without entering independent variables.

\section{DISCUSSION OF RESULTS}

The feasibility test of the model can be seen from two aspects, the first is whether the model formed in substance can be interpreted by the discipline involved. Substantially, it can be seen from the explanatory variables used in explaining farmers' interest in using information technology in marketing agricultural products to produce results in accordance with existing theories and facts.

While statistically the model feasibility test in this study was seen from three criteria, namely the overall test (Omnibus Test of Model Coefficient or G test), Hosmer and Lemeshow Test, and Negelkerke $R$ Square. The results of the overall logistic regression analysis output are presented in Table 1.

Table 1 - Output Logit Regression Analysis of Interest in the Use of Agricultural Product Marketing Methods in IT Utilization

\begin{tabular}{lllllll}
\hline Variable & B & S.E & Wald & df & Sig. & Exp(B) \\
\hline IT Knowledge Level ${ }^{*}$ & .767 & .437 & 3.085 & 1 & .079 & 2.153 \\
\hline Education & .255 & .641 & .158 & 1 & .691 & 1.291 \\
\hline Age & -.166 & .170 & .949 & 1 & .330 & .847 \\
\hline Constanta & -5.033 & 7.565 & .443 & 1 & .506 & .007 \\
\hline Omnibus Test of Model Coefficient & 17.821 & Sig. & .000 & & & \\
\hline Hosmer and Lemeshow Test & 5.708 & Sig. & .680 & & \\
\hline Nagelkerke R Square & .812 & & & & \\
\hline Sig level: ${ }^{*} 10 \%$ & & & & & \\
\hline Number observation 20 & & & & \\
\hline
\end{tabular}

From the output of the test results presented in Table 1 it can be seen that the Omnibus Test of Model Coefficient is 17.82. With a significance value $<0.05$ (Reject $\mathrm{H} 0$ ) means that this model has a confidence level of more than $99 \%$. So it can be concluded that in general there is at least one independent variable that influences farmers' interest in using IT in marketing their agricultural products.

In the criteria of the Hosmer and Lemeshow Test it has a value of 5.708 with a significance value of 0.680 . Because the significance value is greater than 0.05 (Accept $\mathrm{HO}$ ), it can be concluded that the logistic model that was built has been able to explain the data.

Nagelkerke $R$ Square values have quite similar interpretations to linear regression. If the output of the analysis results presented in Table 1, the Nagelkerke R Square value of 
0.812 means that $81.2 \%$ of the variance in the variable of farmer interest in the use of IT in marketing agricultural products can be explained by the independent variables in the model. While the remaining $18.8 \%$ is explained by other variables outside the model. However, because the coefficient of determination in logistic regression cannot be calculated as linear regression and this is only an approach, so to find out how many values can be predicted correctly can be seen from the Classification Plot presented in Table 2.

Table 2 - Output of Classification Table

\begin{tabular}{ccccc}
\hline \multirow{2}{*}{ Observed } & \multicolumn{3}{c}{ Predicted } \\
\cline { 3 - 4 } & & Farmer's Interest in the Use of IT & \multirow{2}{*}{ Percentage Correct } \\
\cline { 3 - 4 } & 0 & 12 & 1 & 92.3 \\
\hline \multirow{2}{*}{ Farmer's Interest in the Use of IT } & 1 & 1 & 1 & 85.7 \\
\hline Overall Percentage & & & & 90.0 \\
\hline
\end{tabular}

In Table 2 it can be seen that the percentage of accuracy in predicting farmers who are interested in using IT in marketing their agricultural products is 92.3 percent where of the 20 respondents who answered no (0) were 12 farmers, while there was one farmer who statistically actually answered yes (1). Meanwhile, for accuracy in predicting respondents who answered interested in using IT in marketing methods amounted to 85.7. With an overall percentage value of 90.0 percent it can be concluded that the model used has the accuracy of predicting how farmers use IT in the marketing process of agricultural products or not is 90.0 percent. Thus the model used is good.

In the logistic regression output results presented in Table 2, it can be seen that from the 3 independent variables used there are 1 independent variables that have a significant effect on the use of information technology in marketing agricultural products. The significant variable is farmers' knowledge of IT.

Based on Table 2 it can be seen that the variable that has the most significant influence is the IT Knowledge Level. This indicates that the interest of farmers in using information technology in marketing agricultural products is strongly influenced by the level of knowledge of farmers related to IT, where the higher level of knowledge of farmers related to IT comes from the knowledge and ability to operationalize IT. If seen from the Exp coefficient value (B) it can be interpreted that farmers who have a higher level of IT knowledge, then on average there will be a 2,153 times higher chance of using IT in marketing than farmers who are less informed about information technology and IT use.

Meanwhile based on the output in Table 2 it can also be seen that age and education level do not significantly influence farmers' interest in marketing using IT. The age and education level variables have no effect because they do not directly influence the interest in the use of information technology in marketing agricultural products.

\section{CONCLUSION}

In this research only one independent variable had a significant effect on the use of information technology in marketing agricultural products, namely farmers' knowledge of information technology. This indicates that farmers' interest in using information technology in marketing agricultural products is strongly influenced by the level of farmers' knowledge related to information technology, that is, if the higher level of farmers' knowledge regarding information technology comes from knowledge and ability to operationalize information technology. Farmers who have a high level of information technology knowledge have a higher chance to use information technology in marketing agricultural products than farmers who are less informed about information technology and use of information technology. Thus the need for information and communication technology training related to the use of technology so that not only uses smartphones for communication, but can be used for marketing media. Therefore, farmers can increase sales volume and product price levels which have an impact on improving farmers' welfare. 


\section{REFERENCES}

1. Elia, E., Lefebvre, L.A., and Lefebvre, E. (2007). Focus of B-to-B ecommerce initiatives and related benefits in manufacturing smalland medium-sized enterprises. Information Systems and E-BusinessManagement, 5(1), 1-23.

2. Fayçal, Mokhtari and Houari Moulay Ali. (2018). Economic Growth and Government Subventions for Agriculture Sector in Algeria: An ARDL Model. Arab Economic and Business Journal 11 105-114. http://dx.doi.org/10.1016/j.aebj.2016.10.001.

3. Frank, Alejandro Germán., Lucas Santos Dalenogare., Néstor Fabián Ayala. (2019). Industry 4.0 technologies: Implementation patterns in manufacturing companies. International Journal of Production Economics 210 (2019) 15-26. https://doi.org/10.1016/j.ijpe.2019.01.004.

4. Fruhling, A.L., and Digman, L.A. (2000). The impact of electronic commerce on businesslevel strategies. Journal of Electronic Commerce Research, 1(1), 13-22.

5. Gouvea, Raul ., Dimitri Kapelianis., Sul Kassicieh. (2018). Assessing the nexus of sustainability and information \& communications technology. Technological Forecasting \& Social Change 130 (2018) 39-44. http://dx.doi.org/10.1016/j.techfore.2017.07.023.

6. Jiang, Hong., Shukuan Zhao., Siwen Zhang., Xiaobo X. (2018). The adaptive mechanism between technology standardization and technology development: An empirical study. Technological Forecasting \& Social Change 135 (2018) 241-248. https://doi.org/10.1016/j.techfore.2017.11.015.

7. Li, Jintao and Yixue Li. (2018). Influence measurement of rapid urbanization on agricultural production factors based on provincial panel data. Socio-Economic Planning Sciences. https://doi.org/10.1016/j.seps.2018.09.004.

8. Melly, W. 2000. Pemanfaatan Jaringan Internet Sebagai salah satu Alternatif Strategi Pemasaran Ekspor Ikan Hias (Studi Kasus CV. Aquatic Indonesia). [Minor Thesis]. Bogor (ID). Jurusan Ilmu-ilmu Sosial Ekonomi Pertanian, Institut Pertanian Bogor.

9. Mohammed, R. A., Fisher, R. J., Jaworski, B. J., \& Paddison, G. J. (2003). Internet Marketing: Building Advantage in a Network Economy. McGraw-Hill.

10. Montealegre, F., Thompson, S., and Eales, J.S. (2007). An empirical analysis of the determinants of success of food and agribusiness e-commerce firms. International Food and Agribusiness Management Review, 10(1), 61-81.

11. Pranata, Takhlishul D. 2015. Jurnal Journal of Economics and Policy [JEJAK]. Pengaruh Harga Bawang Merah Terhadap Produksi Bawang merah di Jawa Tengah (ID). Vol 8 pg 36-44.

12. Sulthoni, M. 2016. Pemanfaatan E-commerce Pada Pemasaran Produk Agribisnis. Malang (ID). Universitas Maulana Malik Ibrahim.

13. Swandayani A. 2014. Pemanfaatan E-Commerce Dalam Meningkatkan Usaha Agribisnis : Sebagai Alternatif Pemberdayaan Komunitas Petani [Thesis]. Depok (ID). Universitas Indonesia.

14. Zhang, Fan., Jinyan Zhan., Qian Zhang., Haiming Yan., and Zhongxiao Sun. (2018). Allocating agricultural production factors: A scenario-based modeling of wheat production in Shandong Province, China. Physics and Chemistry of the Earth 55-63. http://dx.doi.org/10.1016/j.pce.2016.06.002. 